\title{
A Strategy to Improve the Learning of Political Culture with Debate Method in Vocational High School 1 Bekasi \\ Kurniawan Prambudi Utomo ${ }^{1}$, Fahmi Kamal ${ }^{2}$ \\ Universitas Bina Sarana Informatika \\ ${ }^{1}$ kurniawan.kpu@bsi.ac.id*; fahmi.fmk@bsi.ac.id
}

\begin{abstract}
This research was conducted to form one part of national education and improve the culture of literacy among vocational students who are effective and efficient as well as to train intelligence and the ability to manage emotionally elegant so that it is expected to prepare future leaders. The purpose of this research is to examine the variables of political culture material with the method while the methodology of this research is Classroom Action Research (CAR) or Classroom Action Research. This class action research is a form of self-reflection carried out by researchers that are seen in the situation under study aimed at improving the quality of learning, as well as to improve the performance of the education system using a qualitative approach, the time of the implementation of this study was carried out for three months, namely in June - September 2017 and the results of the study concluded that in the early stages of the cycle the increase in student understanding reached $62.5 \%$ and considered sufficient to understand while the research in the final cycle, after the given direction, and ability, students showed the role of some students quite significant, reaching $22.5 \%$ of students so that the understanding of political culture debate reached $100 \%$.
\end{abstract}

Keywords:

Students, Political Culture, Debate Method

This is an open access article under the CC-BY-NC license.

\section{INTRODUCTION}

Education is a core effort in the process of developing human resources. With human education consciously will be directed to develop its potential in the form of abilities, skills, attitudes, and personalities by the objectives of national education. Education is a necessity for every developing nation like Indonesia. With education it is hoped that the creation of a strong and strong Indonesian human being in dealing with various social and individual problems. The subject of civic education focuses on the formation of citizens who understand and can carry out their rights and obligations to become smart, skillful, and characterized Indonesian citizens as mandated by Pancasila and the 1945 Constitution. Normatively, according to Syarbaini (2003), citizenship education says that citizenship education obtains the basis of the punishment stipulated in Article 3 of Law No.20 of 2003 concerning the National Education System which reads: "National Education functions to develop capabilities and shape the character and civilization of a dignified nation to educate the life of the nation". While the Ministry of 
Education and Culture defines the above the development of the era, the conditions provisions must be understood as education that will develop capabilities and shape the character of the nation based on values that grow, live and develop in the life of the nation and state. Through Civics, students are expected to have and develop their potential both as members of the community, nation, and state and as members of the community both for themselves and for the continuity of daily life in the community to become good citizens. Based on observations and experiences in class so far, students have less interest in learning Civics. This can be seen from several indications shown by student behavior when the teaching and learning process takes place. For example students are less active and enthusiastic when the learning process takes place. Students tend to be less interested in Civics learning because all this time there are assumptions that Civics learning is boring and only focuses on memorizing, less emphasis on reasoning aspects, causing low understanding of students. The atmosphere of teaching and learning is expected to make students as subjects who try to explore themselves, solve their problems of a concept being studied, while the teacher acts more as a motivator and facilitator. The expected learning situation here is students who have more (creative) roles. Along with of learning and teaching also have many learning methods that support to increase the activeness of students in the learning process, and one of the innovations that are a breakthrough in the world of education today is an active learning method (active learning), namely the debate method ", this is according to the Method derived from the Greek "Methodos" which means the way or path taken. Meanwhile, according to Sanjaya, the method covers the problem of how to work to be able to understand the object that is the target of the relevant science. Hamalik (2007) said that the function of the method means as a means to an end. The understanding cited by Hidayat (2010) of the active debate method is a debate that can be a valuable method for developing thought and reflection, especially if students are expected to take positions that are contrary to their opinions. This is a strategy for an active debate involving every student in the class, not just the people involved, according to Hidayat (2010), saying that the active debate method is a method of discussion in the form of debate carried out by giving an issue that as far as possible controversial so that there will be opinions that differ from students. In expressing students' opinions, they are required to use strong arguments that originate from class materials, while 
the debating method can take the form of rhetoric which is divided into two parts, namely monologic and dialogics. Monolog is the art of speaking monologically or speaking in one direction, that is, there is only one person who speaks while the others are only listeners. There are various monologies including: speeches, lectures, recitations, and so on. Teachers must be able to direct this debate at the core of the subject matter to be understood. The debate method is one of the most important learning methods not only to improve students' academic abilities but also to train students to be able to think critically, analytically, and constructively, and to be sporty. In the debate method students are not only required to be able to understand the material that is analyzing in a short time and good, the ability to control emotions is also very necessary in this case learning in the classroom becomes more alive because it involves students directly.

\section{THEORETICAL PERSPECTIVES}

Research Method

The method used in this study is Classroom Action Research (CAR) or Classroom Action Research which has recently become a trend of education teachers who lately pay a lot of attention to class action research. This classroom action research is a form of self-reflection conducted by researchers who are seen in the situation under study aimed at improving the quality of learning, as well as improving the performance of the education system. The approach used in this study is qualitative. The choice of this approach is because the type of research is classroom action research (CAR). The data sources of this research are students of class XI AK in SMK Negeri 1 Bekasi (informants) and teachers in class XII Civics studies at SMK 1 Bekasi City (key informants) and where the research was conducted at SMK Negeri 1 The City of Bekasi which addressed and the time of the research was carried out for three months, June- September 2017.

\section{FINDINGS AND DISCUSSION}

1. Action Research and Preliminary Cycle Research Findings

Cycle 1 was held on Monday 10 September 2017 at the 3rd and 4th class hours, at $08.30-10.00$ with an allocation of $2 \times 45$ minutes Cycle 1 is the first step that determines the next cycle because in this cycle there are efforts to reform the civic education learning interaction process in SMK Negeri 1 Bekasi, while the steps which are the stages of the reform process include:

\section{A. Planning}

The plans prepared include: preparing lesson plans, setting competency standards 
and basic competencies, selecting learning system using the debate method appropriate lesson material, determining then the researcher and the collaborator learning scenarios with contextual teacher divide students into two groups, approaches, and problem-based learning each group consisting of 5 students and the (PBL) preparing the source of materials and tools needed, compiling student worksheets, developing a learning observation format.

B. Action Implementation

After making preparations, namely the implementation of the concepts that have been prepared in the learning process, there are several stages in the implementation of classroom actions

1). Initial activity other students become the audience. The atmosphere in the class spontaneously occurs noise because some students want to choose their classmates but researchers can overcome student noise and convince students that the grouping of students in the first cycle is based on students who have high criteria of speech/debate skills then the researcher guides the students to arrange seating the pros and cons group sat in front of the class, while the teacher and

After explaining the theory and pre-test, researcher were observers and moderators. the teacher and researcher explain the

Table 1. List of Student Names in the Pro and Counter Groups

\begin{tabular}{|c|c|c|c|}
\hline \multirow{2}{*}{ No } & Pro Group & \multirow{2}{*}{ No } & Counter Groups \\
\cline { 2 - 2 } \cline { 4 - 4 } & Student Names (Initial) & & Student Names (Initial) \\
\hline 1 & A & 1 & I \\
\hline 2 & B & 3 & II \\
\hline 3 & C & 4 & III \\
\hline 4 & D & 5 & IV \\
\hline 5 & F & 6 & V \\
\hline 6 & G & 7 & VI \\
\hline 7 & H & 8 & VII \\
\hline 8 & I & 9 & VIII \\
\hline 9 & J & 10 & IX \\
\hline 10 & K & 11 & X \\
\hline 11 & L & 12 & XI \\
\hline 12 & M & 13 & XII \\
\hline 13 & N & 14 & XIII \\
\hline 14 & O & 15 & XIV \\
\hline 15 & P & & XV \\
\hline
\end{tabular}

Source: Student Date, 2017 
Table 2. The following is the arrangement of student seats during the debates:

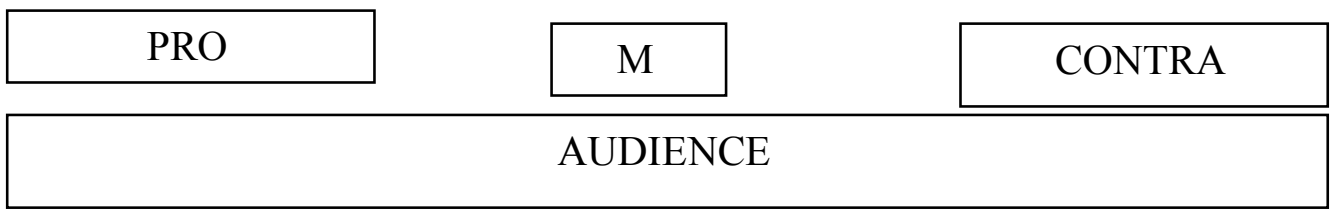

Information:

Pros: Pro group with spokesman "A"

Cons: City group with spokesman "I"

M: Moderator (Teacher)

P: Observer (researcher)

Audience: other students numbering 30 people

These pros and cons groups are chosen based on the ability of the level of understanding of the material and the ability to speak good/high students. The division of these groups are shown in table 1.

The purpose of the seating arrangement is for the pros and cons groups to issue their opinions, ideas and ideas to the audience. These pros and cons groups are considered to have a high level of speaking ability in front of this class, later it is hoped that it will be able to lure other students to dare to express their opinions. While the task of the moderator here is to control the debate situation to accommodate the ideas of the audience and also as a stimulus to groups of pros and cons to be even more courageous in issuing their opinions. While the presence of the observer here is to monitor the nets of the debate to be conducive.

After the seating arrangement is finished the teacher asks each group leader to take an envelope which contains the debate material and the group's position as a pro or contra group. The pro group is chaired by "A" with a spokesman for "I" and a counter group headed by "B" with spokesman "II". Furthermore, the contentious material is "Participatory Political Culture in Indonesia Has Been Going Good" The pro group positioned its group as a group that agreed to the statement that the participant's political culture in Indonesia had gone well while the counter group positioned its group as a group that opposed the statement that in Indonesia political culture participants have not been going well.

The teacher gives time for each group to prepare material / material on the theme that has been prepared. After +10 minutes the pros and cons groups prepare the material / debate then the debate begins with the arguments / opinions of the pro groups represented by the spokesman "II" "According to our group the participant's 
political culture has been going well in Indonesia, this is evidenced by the participation of the Indonesian people in Good elections become active voters and some even become members of the people's representatives "opening arguments have been submitted by pro groups, then the moderator begins to provoke the contra group's intimacy:" Does the whole level of Indonesian society already understand what is the political culture of the participants, given the diversity of diversity in our country? "The contra group represented by spokesperson "B" began issuing his opinion" I disagree with the opinion of the pro groups, that the reality in the field, that the political culture of the participants has not yet fully touched all levels of society is evidenced by the still lack of people in the countryside to freely express their opinions especially during the election, they are still many who are confused when voting / voting "

The statement from the contra group spontaneously made the pro group represented by " $\mathrm{B}$ " start speaking again "that's just an example of a small part, now there are many NGOs, which stand in rural areas so automatically rural communities begin to learn or know about government policies and even there is a show the taste of farmers who oppose the price of dried unhulled rice which is considered detrimental to farmers shows that in rural communities began to dare to express their opinions ". Information from the pro group made the audience nodded, frowned, and some even smiled on their own. Here the moderator starts to open the opportunity for the audience to issue their opinions, but because of confusion or lack of understanding, the audience is silent. While the pro and counter groups began to be seen actively expressing their opinions, each moderator began writing ideas, arguments and the core of each discussion on the board and until a number of ideas expected by the moderator were fulfilled.

\section{2) Final activities}

The final activity begins with commenting by the researcher about the best arguments made by the two groups, then giving feedback to students about the political culture of participants who developed in Indonesia. Next the researcher ordered the students to reflect on the learning on that day by giving written tests and distributing questionnaires. After all students complete the written test sheets and questionnaire, the teacher presents the debate themes that will be held at the meeting next (cycle 2) then the researcher closes the lesson by saying greetings and guiding students to tidy up their seats. 


\section{A. Observation}

After observing in the field when the debate took place most students looked still passive (silent) as if they were still confused and uncomfortable to express their opinions. Students who are divided into two groups, namely the pros and cons groups have not been able to apply an active debate in dealing with the theme at hand. In dealing with themes in groups. Most students still rely on friends who are considered able to express their opinions and have not been able to express their opinions on existing themes based on their own understanding.

\section{B. Reflection}

Based on the observations above in the first cycle learning there are some things that have been done but there are still many shortcomings, things that have been done in the first cycle are as follows:

1) Students have started to adapt to the learning process with the debate method

2) Some students have the courage to express opinions (argue)

3) The teacher has been able to create a pleasant learning atmosphere

Weaknesses that are still found in cycle 1 learning are as follows:
1. Students have not been able to formulate the subject matter that is the subject of public debate (controversy)

2. Students have not been able to appreciate the opinions of opponents debate

3. Students have not been able to look active in debates

4. The teacher is too fast when implementing the material

5. The teacher is less assertive towards students when moderating

6. The volume of the teacher's voice is not heard by all students

7. The teacher has not been able to use the time allocation properly

Based on the results of the first cycle test 1 (one) it is known that as many as 15 students are of less value, 6 students of medium value and 9 students of good value in this cycle the increase in understanding of students reached $62.5 \%$ of students lacking understanding and while for an average class of 72.25 or 72 classified into the medium category and have not yet reached KKM 75 which has set. Based on observations and tests researchers consider students' ability to debate and understanding students are still lacking so it is necessary to hold further learning in cycle 2 . 
2. Conduct Action Research and Final Cycle Research Findings

Cycle II was carried out on Monday, September 17, 2017 during class 3 and 4 hours, at $08: 30$ to $10: 00$ with an allocation of time of $2 \times 45$ minutes. The stages of learning in cycle II are not much different from the initial cycle. As for the stages of learning in the second cycle are as follows:

\section{A. Planning,}

As in the initial cycle, in the final cycle begins with preparing an improvement plan that will later be implemented in implementation. By combining the results of reflection cycle I and the final cycle plan, it is hoped that there will be an increase in the quality of students' interest in understanding civic education subjects, political culture material. Furthermore, they prepare observation and evaluation sheets as a form of analysis in knowing the development of student understanding.

\section{B. Action Implementation}

\section{Initial activity}

After stimulating students knowledge about the socialization of the development of political culture, the researcher held a Question and Answer to students about the socialization material development of political culture. Then the researchers redivided students into 3 groups. In the initial cycle of pros and cons groups. Researchers joined to become moderators, and the audience in the first cycle, researchers broke into 2 groups of pros and cons, instructed researchers to choose their respective spokespersons.

The classroom atmosphere starts to become noisy, because students want to choose their own friends in the same group. However, the situation can be overcome by telling researchers that each group has been determined by researchers and teachers. Next, the researcher guides the students to arrange the seating arrangement, forming a square facing each other. The purpose of the seating arrangement is to create a conducive atmosphere for debate activities.

The seating arrangement took place in an orderly manner. Entering learning activities using the debate method, the teacher asks each of the two groups to come forward and take the envelope containing the themes and positions in the debate as a pro or contra group. Before the breakdown begins each group discusses the theme to be debated, namely the role of the mass media in developing one's political culture. The following is the division of moderator groups, pro groups and contra groups in the final cycle debate. The researcher explained the rules of debate which were divided into two sessions, each session was held for 30 
Table 3. List of Student Names in the Pro and Counter Groups

\begin{tabular}{|c|c|c|c|c|}
\hline \multirow{2}{*}{\multicolumn{2}{|c|}{\begin{tabular}{|c|} 
No \\
Source: D
\end{tabular}}} & \multirow{2}{*}{\begin{tabular}{|c|} 
Pro Group \\
ate Stustudent \\
\end{tabular}} & \multirow{2}{*}{ No } & \multirow{2}{*}{$\begin{array}{c}\text { Counter Groups } \\
\text { Student Names (Initial) } \\
\end{array}$} \\
\hline & & & & \\
\hline $\mathrm{H}$ & 1 & A & 1 & I \\
\hline e & 2 & B & 2 & II \\
\hline & 3 & $\mathrm{C}$ & 3 & III \\
\hline c & 4 & $\mathrm{D}$ & 4 & IV \\
\hline 0 & 5 & $\mathrm{~F}$ & 5 & $\mathrm{~V}$ \\
\hline$t$ & 6 & $\mathrm{G}$ & 6 & VI \\
\hline$i$ & 7 & $\mathrm{H}$ & 7 & VII \\
\hline$n$ & 8 & I & 8 & VIII \\
\hline $\mathrm{u}$ & 9 & $\mathrm{~J}$ & 9 & IX \\
\hline e & 10 & $\mathrm{~K}$ & 10 & $X$ \\
\hline d & 11 & $\mathrm{~L}$ & 11 & $\mathrm{XI}$ \\
\hline & 12 & $\mathrm{M}$ & 12 & XII \\
\hline 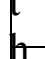 & 13 & $\mathrm{~N}$ & 13 & XIII \\
\hline II & 14 & $\mathrm{O}$ & 14 & XIV \\
\hline & 15 & $\mathrm{P}$ & 15 & $\mathrm{XV}$ \\
\hline
\end{tabular}

Source: Student Date, 2017

minutes and the debate would be guided by students as moderators who would provoke the pro and contra groups. researchers and teachers as observers and guide the implementation of the debate so that students' arguments do not get out of the topic being debated.

The teacher gives an introduction about the role of the mass media in developing one's political culture. Next, the teacher instructs each group the pros and cons to prepare the pros as the material first. Here the pro groups as supporters of the role of mass media in developing one's political culture will have a positive impact. While the counter group as opponents of the role of mass media in developing one's political culture because it will bring negative impacts. The debate began with the opinions of the pro groups represented by Jamaudin, "we think that the mass media has a positive impact on the development of one's political culture because, with the mass media, we can know the political situation of other countries, this will encourage us to know the political conditions in our country with other countries, so we can find out what are the strengths and weaknesses of our country. " Then the moderator began to speak out, represented by "I", "does the mass media forever have a positive impact on the development of one's political culture socialization, given that our country's 
culture is different from other countries?" Then the contra group began to argue represented by "A", "we agree with the moderator, that the mass media harms the development of one's political culture because the mass media likes to present the political situation of other countries, which is ideologically different from our country, Indonesian youths may act later anarchist towards the government's decision, which will later threaten the life of the nation and state. 'The atmosphere of the debate began to warm, alternately the pros and cons groups arguing with each other. While students present their ideas, the teacher writes the core/ideas of each discussion on the board, until several ideas that the teacher hopes are met do not forget the teacher adds concepts/ideas that have not been revealed.

\section{Final activities}

The final activity begins with commenting by the researcher about the best arguments made by the two groups, then giving feedback to students about the development of political culture socialization from the data on the board, the teacher invites students to make conclusions/summaries that refer to the topic they want to achieve. Next the teacher gives a written test to find out the students' abilities of the material that has been learned and distribute questionnaires. After all, students have completed the test and questionnaire, the researcher guides the students to tidy up their seats, and remembers students to prepare the debate material for the next meeting. Then the researcher closes the lesson by saying greetings.

\section{A. Observation}

The observations show, students already have an interest in learning civic education subjects which are marked by their activity asking questions and submitting opinions. Even though they do not have many ideas but at least the laziness and boredom of students has begun to disappear and change their enthusiasm for the lesson civics learning strategies with this debate technique also have an increasingly positive impact, this is because students are trained to be more active in communicating between students and are more willing to submit opinions and criticize their friends' opinions.

\section{B. Reflection}

Based on the observations above, in the second cycle of learning, several things have been done. But there are also deficiencies. Things that have already been done. But there are also deficiencies, things 
that have been done in the second cycle are as follows:

1. Students can formulate the subject matter that is the subject of public debate (controversy)

2. Students have started to be active

3. Students feel happy with Civics learning with debate techniques

4. Some students dare to express opinions (argument)

5. Students begin to be able to appreciate the opinions of the other person in the debate.

Based on the results of observations and tests at the end of the cycle, the researcher considers the ability of students in debating to have progressed, although it still needs to be improved, while students' understanding begins to increase, but still needs to be improved again, Based on the results of observations and tests at the end of the cycle, the researchers considered the students' ability to debate had progressed, although it still needed to be improved, at the end of the cycle, after being given directions, and the ability, students showed the role of some students quite significant, reaching $22.5 \%$ of students so that the understanding of political culture debate reaches $100 \%$ and while for an average class of 72.25 or 72 classified into the medium category and have not yet reached minimal completeness criteria 75 which has set.

\section{CONCLUSION}

In the initial cycle it has not been seen that student activity has not increased, but students have been able to conduct discussions through debate methods, that mean it means that from this class action research it is known that the pre-debate method has not shown the desired results that the participants have not maximally issued the ability to both defend and attack the opponent's debate with their respective instruments, so it is necessary to emphasize again from the method by repeating in different ways and understand the material presented by the teacher in the field of Civics studies in discussing the themes presented so that students are expected to be more active again, in this cycle increasing the understanding, result of the study concluded that in the early stages of the cycle the increase in student understanding reached $62.5 \%$ and considered sufficient to understand while the research in the final cycle, after given direction, and ability, students showed the role of some students quite significant, reaching $22.5 \%$ of students so that the understanding of political culture debate reached $100 \%$. 


\section{REFERENCES}

Hamalik, Oemar, (2007). Management of Curriculum Development, Bandung: PT. Teens Rosda Karya.

Syahrial, Syarbaini et al. (2003). Building Character and Personality through Citizenship Education. Jakarta. Graha Sciences, p. 3.

Ministry of the National Education Republic of Indonesia. Law of the
Republic of Indonesia Number 20 of 2003 concerning the National Education System. P. 3.

Sanjaya, Wina, (2006). Process - Oriented Learning Strategies for Education Process Standards. Jakarta. Kencana Prima, p. 174.

Kamarudin, Hidayat. (2010). debate method strategy. Jakarta. Kencana Prima. p. 70. 